Vol 1. No 2. November 2021, e-ISSN : 2807-1808 | P-ISSN : 2807-2294

\title{
PENGARUH KOMITMEN ORGANISASI DAN KEAKTIFAN SISWA TERHADAP MINAT BELAJAR SISWA DI SMA NEGERI 3 BABELAN
}

\author{
DEDE HENDARDI \\ Pascasarjana PMIPA, Universitas Indraprasta PGRI, Jakarta \\ e-mail: dhendardi@gmail.com
}

\begin{abstract}
ABSTRAK
Tujuan dari penelitian ini adalah untuk mengetahui: 1) Pengaruh komitmen organisasi terhadap minat belajar siswa SMA Negeri 3 Babelan tahun ajaran 2020/2021. 2) Pengaruh keaktifan siswa terhadap minat belajar siswa SMA Negeri 3 Babelan tahun ajaran 2020/2021. 3) Pengaruh komitmen organisasi dan keaktifan siswa terhadap minat belajar siswa SMA Negeri 3 Babelan tahun ajaran 2020/2021. Penelitian ini termasuk jenis penelitian deskriptif kuantitatif dengan penarikan kesimpulan melalui analisis statistik. Populasi dalam penelitian ini adalah pengurus OSIS dan Anggota ekskul SMA Negeri 3 Babelan tahun ajaran 2020/2021. Sampel diambil sebanyak 90 orang siswa dengan teknik random sampling. Data yang diperlukan diperoleh melalui angket dan dokumentasi. Angket sebelumnya diuji cobakan dan diuji validitas serta diuji reliabilitas. Kesimpulan dari penelitian ini adalah 1) Terdapat pengaruh yang signifikan komitmen organisasi $\left(\mathrm{X}_{1}\right)$ terhadap minat belajar siswa $(\mathrm{Y})$. Hal ini berdasarkan analisis regresi linier ganda (uji t) diketahui bahwa thitung $>t_{\text {tabel, }}$ yaitu 3,883 $>1,66$ dan nilai signifikansi $\alpha=$ 0,05 . 2) Terdapat pengaruh yang signifikan keaktifan siswa $\left(X_{2}\right)$ terhadap minat belajar siswa (Y). Hal ini berdasarkan analisis regresi linier ganda (uji $t$ ) diketahui bahwa $t_{\text {hitung }}>t_{\text {tabel, }}$ yaitu $4,021>1,66$ dan nilai signifikansi $\alpha=0,05$. 3) Terdapat pengaruh yang signifikan secara simultan komitmen organisasi $\left(\mathrm{X}_{1}\right)$ dan keaktifan siswa $\left(\mathrm{X}_{2}\right)$ terhadap minat belajar siswa $(\mathrm{Y})$. Hal ini berdasarkan analisis regresi linier ganda (uji t) diketahui bahwa $t_{\text {hitung }}>t_{\text {tabel }}$, yaitu $19,888>3,10$ dan nilai signifikansi $\alpha=0,05$.
\end{abstract}

Kata Kunci: Komitmen Organisasi, Keaktifan Siswa, Minat Belajar Siswa

\section{ABSTRACT}

The purpose of this study was to determine: 1) The effect of organizational commitment on student interest in learning at SMA Negeri 3 Babelan for the academic year 2020/2021. 2) The effect of student activity on student interest in SMA Negeri 3 Babelan for the 2020/2021 academic year. 3) The effect of organizational commitment and student activity on student interest in learning at SMA Negeri 3 Babelan for the academic year 2020/2021. This research belongs to the type of quantitative descriptive research with conclusions drawn through statistical analysis. The population in this study were OSIS administrators and extracurricular members of SMA Negeri 3 Babelan for the 2020/2021 academic year. Samples were taken as many as 90 students with random sampling technique. The required data was obtained through questionnaires and documentation. The previous questionnaire was tested and tested for validity and tested for reliability. The conclusions of this study are 1) There is a significant effect of organizational commitment $\left(\mathrm{X}_{1}\right)$ on students' interest in learning $(\mathrm{Y})$. This is based on multiple

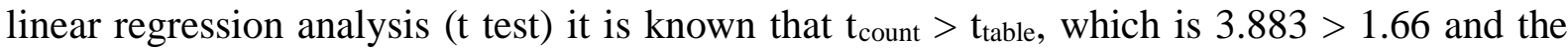
significance value $=0.05$. 2) There is a significant effect of student activity $\left(\mathrm{X}_{2}\right)$ on student interest in learning (Y). This is based on multiple linear regression analysis ( $t$ test) it is known that $t_{\text {count }}>t_{\text {table, }}$ which is $4.021>1.66$ and the significance value $=0.05$. 3) There is a simultaneous significant effect of organizational commitment $\left(\mathrm{X}_{1}\right)$ and student activity $\left(\mathrm{X}_{2}\right)$ on students' interest in learning (Y). This is based on multiple linear regression analysis ( $t$ test) it is known that $t_{\text {count }}>t_{\text {table, }}$, which is $19.888>3.10$ and the significance value $=0.05$.

Keywords: Organizational Commitment, Student Activity, Student Interest 


\section{PENDAHULUAN}

Pendidikan merupakan upaya belajar mengajar dalam meningkatkan kemampuan siswa baik secara kecerdasan, tingkah laku atau sikap, dan keterampilan yang berguna bagi diri sendiri, masyarakat bangsa dan negara. Pentingnya pendidikan bertujuan untuk mengurangi kebodohan dan mencerdaskan setiap orang agar kehidupan menjadi lebih baik. Dalam pendidikan banyak faktor yang mempengaruhi tinggi rendahnya prestasi belajar yang diperoleh siswa, baik faktor internal maupun eksternal. Menurut Ahmadi dan Supriyono (2004: 138) prestasi belajar yang dicapai seseorang merupakan hasil interaksi berbagai faktor yang mempengaruhinya baik dalam diri (faktor internal) maupun dari luar (faktor eksternal). Faktor internal meliputi minat belajar, keaktifan siswa, gaya belajar, dan lain-lain. Sedangkan faktor eksternalnya meliputi fasilitas belajar, perhatian orang tua, lingkungan belajar, dan sebagainya.

Faktor lain yang dapat mempengaruhi prestasi belajar yaitu komitmen organisasi. Kanter (dalam Raju dan Srivastava, 1994: 7) menyebutkan bahwa komitmen sebagai sebuah minat individu yang melekat pada pola perilaku sosial yang teroganisir. Sedangkan menurut Sopiah (2008: 155), komitmen organisasi adalah derajat yang mana siswa percaya dan menerima tujuan-tujuan organisasi dan akan tetap tinggal atau tidak akan meninggalkan organisasi. Dari pendapat tersebut dapat dipahami bahwa komitmen organisasi merupakan minat individu yang melekat pada perilaku sosial untuk bertahan menjadi anggota, percaya, dan menerima tujuan organisasi, serta bertahan di organisasi untuk mewujudkan tujuan organisasi. Oleh karena itu, komitmen organisasi dapat memotivasi siswa untuk meraih kinerja yang tinggi. Mayer \& Herscovitch (2001) menjelaskan bahwa individu yang memiliki komitmen organisasi dan profesionalisme tinggi maka akan menunjukan perilaku yang baik. Oleh karena itu, komitmen organisasi dapat memotivasi siswa untuk meraih prestasi yang lebih tinggi.

Keberhasilan pencapaian tujuan pendidikan dapat dilihat dari salah satu indikatornya yaitu keaktifan belajar siswa. Keaktifan belajar dapat dipandang sebagai tolak ukur dalam keberhasilan suatu kegiatan pembelajaran yang biasanya ditunjukkan dengan tinggi rendahnya partisipasi siswa dalam memberikan respon selama proses pembelajaran. Menurut Dimyati dan Mudjiono (2010:45) dalam setiap proses belajar, siswa selalu menampakkan keaktifan. Keaktifan itu beraneka ragam bentuknya. Mulai dari kegiatan fisik yang mudah kita amati sampai kegiatan psikis yang susah diamati. Berdasarkan Taksonomi Bloom, untuk mengetahui keaktifan siswa dalam pembelajaran di kelas dapat dilihat dari aspek afektif karena dalam ranah afektif mencakup watak perilaku seperti perasaan, minat, sikap, emosi, atau nilai. "Sikap (attitude) adalah kecenderungan yang relatif menetap untuk bereaksi dengan cara baik atau buruk terhadap orang atau barang tertentu" (Bruno dalam Syah, 2008:120).

Kunci utama pembelajaran adalah minat, pembelajaran akan terjadi jika siswa memiliki minat untuk belajar. Menurut Slameto (2003: 57) minat belajar besar pengaruhnya terhadap prestasi belajar, karena jika bahan pelajaran yang dipelajari tidak sesuai dengan minat siswa, maka siswa tidak akan belajar dengan baik-baik. Minat merupakan bentuk sikap dan ketertarikan atau sepenuhnya terlibat dengan suatu kegiatan karena menyadari pentingnya atau bernilainya kegiatan tersebut (Sudarsono, 2003:28). Dengan adanya minat kegiatan belajar mengajar akan berjalan dengan baik dan seseorang akan lebih berkonsentrasi, tidak mudah bosan dan mudah untuk mengingat dengan apa yang dipelajari. Hal itu sesuai dengan yang dikatakan oleh S. Nasution (1998: 58) bahwa pelajaran akan berjalan lancar apabila ada minat. Anak-anak malas, tidak belajar, gagal karena tidak ada minat. Hal tersebut dapat terjadi pada saat guru menjelaskan dan memberikan pertanyaan - pertanyaan kepada siswa. Namun respon siswa justru tidak berbanding lurus. Ada siswa yang mengobrol dengan temannya, tiduran dengan kepala di atas meja, dan ketika diberikan kesempatan bertanya, tidak ada siswa yang memberikan pertanyaan.

Setiap proses pembelajaran tentunya diharapkan peserta didik memperoleh hasil belajar yang baik. Namun pada kenyataannya hasil belajar yang diperoleh siswa tidak selalu baik dan sesuai harapan. Sebagaimana yang menjadi standar baik atau tidaknya hasil belajar atas dasar KKM yang telah ditetapkan sebagai patokan keberhasilan proses pembelajaran. Hal ini harus 
menjadi perhatian dan bahan evaluasi dalam proses pembelajaran. Hasil belajar siswa yang belum baik menjadi salah satu permasalahan dalam pendidikan. Hasil belajar siswa menunjukkan kemampuan dan kualitas siswa sebagai dampak dari proses pembelajaran yang telah dilaluinya. Melton menyiratkan bahwa hasil belajar merupakan tindakan dan pertunjukan yang mengandung dan mencerminkan kompetensi peserta didik yang berhasil menggunakan konten, informasi, ide-ide dan alatalat dalam pembelajaran. Oleh karena itu hasil belajar dapat didefenisikan sebagai kompetensi dan keterampilan yang dimiliki siswa setelah masa pembelajaran (Molstad \& Karseth, 2016).

Hasil studi pendahuluan menunjukkan bahwa hasil belajar siswa belum optimal. Hal tersebut tercermin dari hasil belajar siswa yang belum mencapai standar KKM. Pertanyaan yang timbul dari permasalahan tersebut adalah mengapa hasil belajar siswa belum optimal?. Merujuk pada perspektif teori belajar bahwasannya banyak faktor yang mempengaruhi hasil belajar siswa, baik secara internal maupun eksternal. Faktor internal meliputi minat belajar, keaktifan siswa, gaya belajar, dan lain-lain. Sedangkan faktor eksternalnya meliputi fasilitas belajar, perhatian orang tua, lingkungan belajar, dan sebagainya.

Komitmen organisasi di ukur, untuk mengetahui komitmen siswa dalam pembelajaran. Sedangkan keaktifan siswa dan minat belajar merupakan faktor internal yang mempengaruhi hasil belajar. Apabila minat belajar siswa sudah tinggi, maka akan berbanding lurus dengan hasil belajar. Berdasarkan uraian diatas, peneliti tertarik untuk melakukan suatu penelitian dengan judul "Pengaruh Komitmen Organisasi dan Keaktifan Siswa terhadap Minat Belajar Siswa di SMA Negeri 3 Babelan". Peneliti ingin mengetahui pengaruh dari komitmen organisasi dan keaktifan siswa terhadap minat belajar siswa.

\section{METODE PENELITIAN}

Metode yang digunakan dalam penelitian ini adalah penelitian deskriptif dengan pendekatan kuantitatif. Pendekatan kuantitatif digunakan karena data penelitian yang diperoleh menggunakan angka-angka dan analisisnya menggunakan statistik. Penelitian ini dilaksanakan di SMA Negeri 3 Babelan pada semester genap dengan populasi sebanyak 90 siswa yakni sampelnya diambil secara random dari para pengurus OSIS dan anggota ekskul. Variabel penelitian dalam penelitian ini adalah variable independen atau variabel bebas yaitu komitmen organisasi $\left(\mathrm{X}_{1}\right)$ dan keaktifan siswa $\left(\mathrm{X}_{2}\right)$ serta variable dependen atau terikatnya adalah minat belajar siswa (Y). Sedangkan teknik pengumpulan data menggunakan angket dan dokumentasi. Metode angket yang digunakan adalah metode angket tertutup secara langsung karena responden hanya tinggal memberi tanda checklist $(\sqrt{ })$ pada salah satu jawaban yang dianggap benar dan penilaian angket menggunakan skala likert dengan menghilangkan option "raguragu" dalam instrument penelitian untuk memudahkan peneliti melihat sikap siswa sesungguhnya sesuai angket yang responden isikan. Sedangkan metode dokumentasinya diperoleh data tentang: gambaran tentang SMA Negeri 3 Babelan, daftar nama yang digunakan sebagai sampel dan try out penelitian, serta nilai siswa SMA Negeri 3 Babelan tahun ajaran 2020/2021 yang diperoleh dari nilai raport.

Instrumen penelitian berupa item-item pernyataan dalam bentuk angket yang sebelumnya sudah diuji cobakan. Hasil uji coba instrumen dianalisis dengan menggunakan uji validitas dan reliabilitas. Item-item yang tidak masuk alam kategori valid dan reliabel didrop atau dibuang. Sedangkan item-item yang dinyatakan valid dan reliabel digunakan sebagai instrumen pengumpulan data penelitian. Hasil pengumpulan data inilah yang kemudian dianalisis. Tahap pertama yaitu dilakukan uji prasyarat analisis yang terdiri dari uji normalitas dan uji linearitas. Setelah memenuhi kriteria pada uji prasyarat analisis langkah selanjutnya adalah melakukan analisis untuk menguji hipotesis yang telah diajukan. Teknik analisis dalam dalam penelitian ini menggunakan analisis regresi linear berganda. 


\section{HASIL DAN PEMBAHASAN}

Hasil analisis terhadap angket untuk mengumpulkan data komitmen organisasi, keaktifan siswa dan minat belajar digunakan skala likert. Skala Likert adalah skala yang dapat dipergunakan untuk mengukur sikap, pendapat, dan persepsi seseorang atau sekelompok orang mengenai suatu gejala atau fenomena pendidikan. Dalam skala Likert terdapat dua bentuk pernyataan yaitu pernyataan positif yang berfungsi untuk mengukur sikap positif, dan pernyataan negative yang berfungsi untuk mengukur sikap negative objek sikap. Skor pernyataan positif dimulai dari 1 untuk sangat tidak setuju (STS), 2 untuk tidak setuju (TS), 3 untuk ragu-ragu (R), 4 untuk setuju (S), dan 5 untuk sangat setuju (SS). Skor pernyataan negative dimulai dari 1 untuk sangat setuju (SS), 2 untuk setuju (S), 3 untuk ragu-ragu (R), 4 untuk tidak setuju (TS), dan 5 untuk sangat tidak setuju (STS). Peneliti menghilangkan option "Ragu-ragu" dalam instrument penelitian untuk memudahkan peneliti melihat sikap siswa sesungguhnya sesuai angket yang responden isikan.

\section{Komitmen Organisasi}

Komitmen organisasi adalah sikap yang mencerminkan sejauh mana seseorang individu mengenal dan terikat pada organisasinya. Individu yang memiliki komitmen tinggi kemungkinan akan melihat dirinya sebagai anggota sejati organisasi. Komitmen organisasi adalah skor dimana seorang siswa terlibat dalam organisasinya dan berkeinginan untuk tetap menjadi anggotanya, dimana di dalamnya mengandung sikap kesetiaan dan kesediaan siswa untuk bekerja secara maksimal bagi organisasinya. Skor yang diperoleh dari instrument komitmen organisasi sebanyak 40 butir pernyataan melalui pemberian angket pada siswa menyangkut beberapa aspek sebagai berikut:

1) Komitmen afektif

2) Komitmen berkelanjutan

3) Komitmen normatif

Adapun instrumen yang digunakan untuk mengumpulkan data komitmen organisasi digunakan skala likert, dengan alternatif jawaban yaitu: $4=$ Sangat Setuju, $3=$ Setuju, $2=$ Tidak Setuju, 1 $=$ Sangat Tidak Setuju jika angket bernilai positif dan sebaliknya jika bernilai negatif.

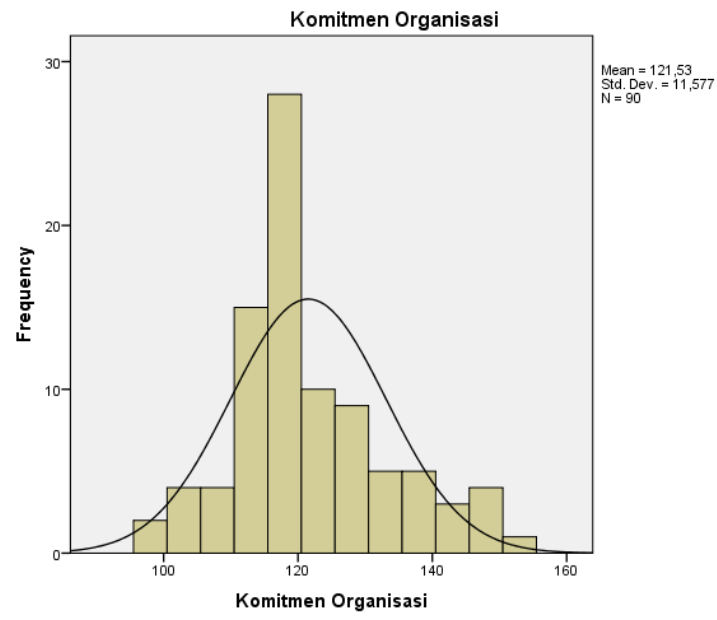

\section{Keaktifan Siswa}

Keaktifan adalah kegiatan atau aktivitas atau segala sesuatu yang dilakukan atau kegiatan-kegiatan yang terjadi baik fisik maupun non fisik. Keaktifan dalam proses pembelajaran dapat merangsang dan mengembangkan bakat yang dimilikinya. Keaktifan siswa adalah skor segala kegiatan yang bersifat fisik maupun non fisik siswa dalam proses kegiatan belajar mengajar yang optimal sehingga dapat menciptakan suasana kelas menjadi kondusif. Untuk variabel keaktifan siswa terdapat dua jenis pernyataan, yaitu pernyataan positif dan pernyataan negatif. Penskoran menggunakan skala Likert yang sudah dimodifikasi dengan empat alternatif jawaban. Skor yang diperoleh dari instrumen keaktifan siswa sebanyak 12 butir 
pernyataan melalui pemberian angket pada siswa. Adapun instrumen yang digunakan untuk mengumpulkan keaktifan siswa dengan alternatif jawaban yaitu: $4=$ Selalu, $3=$ Sering, $2=$ Kadang-kadang, 1 = Tidak Pernah jika angket bernilai positif dan sebaliknya jika bernilai negatif.

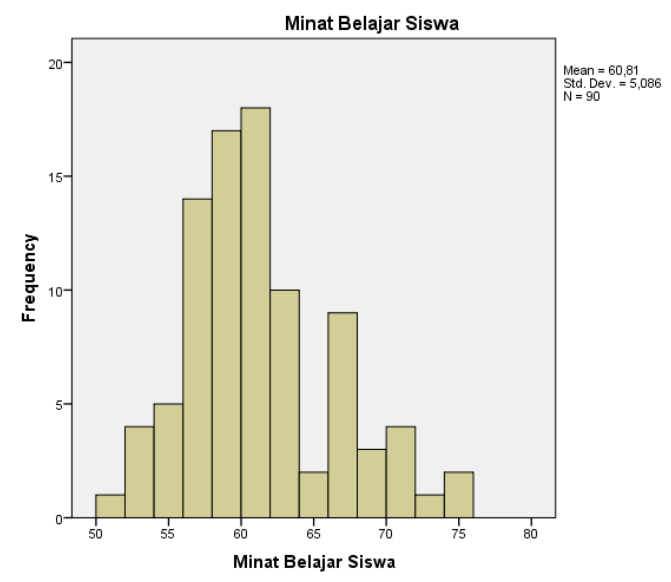

\section{Minat Belajar}

Minat adalah suatu rasa lebih suka dan rasa keterikatan pada suatu hal atau aktivitas, tanpa ada yang menyuruh. Minat pada dasarnya adalah penerimaan akan suatu hubungan antara diri sendiri dengan sesuatu di luar diri. Semakin kuat atau dekat hubungan itu, semakin besar minat. Sementara belajar adalah suatu proses usaha yang dilakukan individu untuk memperoleh suatu perubahan tingkah laku yang baru secara keseluruhan, sebagai hasil pengalaman individu itu sendiri dalam interaksi dengan lingkungannya.

Minat belajar adalah aspek psikologi seseorang yang menampakkan diri dalam beberapa gejala, seperti: gairah, keinginan, perasaan suka untuk melakukan proses perubahan tingkah laku melalui berbagai kegiatan yang meliputi mencari pengetahuan dan pengalaman. Skor yang diperoleh dari instrument minat belajar sebanyak 20 butir pernyataan melalui pemberian angket pada siswa. Minat belajar dapat diungkapkan melalui skala minat belajar yang berdasarkan pada teori minat belajar dari Safari (Wasti, 2013: 8) yang terdiri dari empat indikator minat belajar, yaitu:

1) Perasaan senang.

2) Ketertarikan siswa.

3) Perhatian siswa.

4) Keterlibatan siswa.

Adapun instrumen yang digunakan untuk mengumpulkan data minat belajar digunakan skala likert, dengan alternatif jawaban yaitu: 4 = Sangat Setuju, $3=$ Setuju, $2=$ Tidak Setuju, $1=$ Sangat Tidak Setuju jika angket bernilai positif dan sebaliknya jika bernilai negatif.

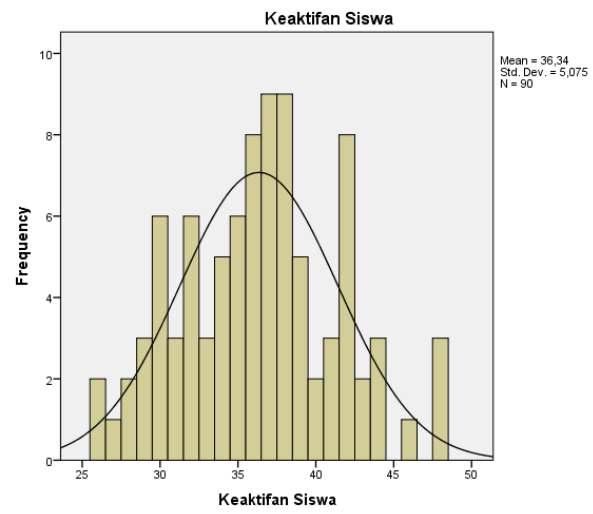


Hasil penelitian menunjukan bahwa komitmen organisasi dan keaktifan siswa berpengaruh terhadap minat belajar. Hal ini bisa dilihat dari persamaan regresi linier sebagai berikut $\mathrm{Y}=28,64+0,16 \mathrm{X}_{1}+0,37 \mathrm{X}_{2}$. Jika komitmen organisasi $\left(\mathrm{X}_{1}\right)$ dan keaktifan belajar $\left(\mathrm{X}_{2}\right)$ rendah atau sama dengan nol maka rata-rata minat belajat siswa (Y) tetap yaitu sebesar 28,64. Setiap peningkatan komitmen organisasi $\left(\mathrm{X}_{1}\right)$ sebesar 1 satuan, akan berdampak pada peningkatan minat belajar siswa (Y) sebesar 0,16 . Setiap peningkatan keaktifan belajar (X2) sebesar 1 satuan, akan berdampak pada peningkatan minat belajar (Y) sebesar 0,37. Berdasarkan persamaan tersebut terlihat bahwa koefisien regresi dari masing-masing variabel independen bernilai positif, artinya variabel komitmen organisasi dan keaktifan siswa secara bersama-sama berpengaruh positif terhadap minat belajar siswa.

Coefficients $^{\mathrm{a}}$

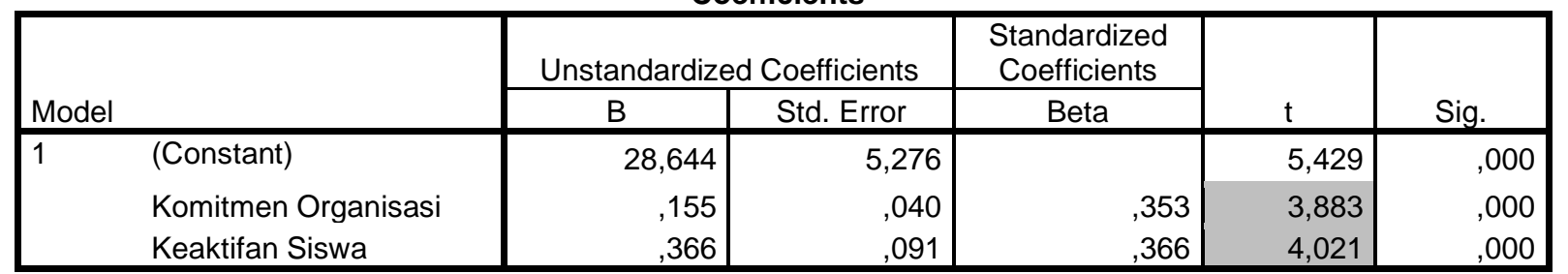

a. Dependent Variable: Minat Belajar Siswa

Hasil uji hipotesis pertama diketahui bahwa koefisien arah regresi dari variabel komitmen organisasi $\left(b_{1}\right)$ adalah sebesar 0,16 atau positif, sehingga dapat dikatakan bahwa variabel komitmen organisasi berpengaruh positif terhadap minat belajar. Berdasarkan uji t untuk variabel komitmen organisasi $\left(b_{1}\right)$ terhadap minat belajar, diperoleh $t_{\text {hitung }}>t_{\text {tabel }}$, yaitu $3,883>1,66$ dan nilai signifikansi $\alpha=0,05$ dengan standar error sebesar 0,04. Berdasarkan hasil tersebut, maka $\mathrm{H}_{0}$ ditolak, dan $\mathrm{H}_{1}$ diterima. Jadi terdapat pengaruh yang signifikan komitmen organisasi terhadap minat belajar. Komitmen organisasi yang tinggi dapat meningkatkan kinerja yang tinggi pula. Hal ini jugalah yang menjadi dasar pemikiran Zein dan Hadijah (2018:60) pada penelitiannya bahwa apabila guru telah memiliki komitmen yang tinggi maka ia akan melakukan usaha yang maksimal dan sukarela untuk kemajuan sekolahnya, terlibat dan berpartisipasi aktif untuk memajukan sekolahnya, serta bertanggungjawab terhadap tugas yang diberikan kepadanya. Sama halnya dengan siswa, apabila sudah memiliki komitmen terhadap organisasi, ia akan melakukan usaha yang maksimal untuk kemajuannya, akan menjadi lebih aktif dan bertanggung jawab terhadap tugas yang diberikan kepadanya. Hasil penelitian ini sejalan dengan temuan Respatiningsih dan Sudirjo (2015:56), Salma (2016:73), Hidayah dan Tobing (2018:122), Rita Hayati, Yasir Arafat, dan Artanti Puspita Sari (2020) yang menyatakan bahwa komitmen organisasi dan motivasi kerja berpengaruh positif terhadap kinerja guru. Hasil penelitian tersebut sejalan dengan komitmen organisasi berpengaruh terhadap minat belajar siswa. Sehingga dapat dikatakan bahwa, semakin baik komitmen organisasi semakin tinggi minat belajar siswa.

Hasil uji hipotesis kedua diketahui bahwa koefisien arah regresi dari variabel keaktifan siswa $\left(b_{2}\right)$ adalah sebesar 0,37 atau positif, sehingga dapat dikatakan bahwa variabel keaktifan siswa berpengaruh positif terhadap minat belajar. Berdasarkan uji t untuk variabel keaktifaan siswa $\left(b_{2}\right)$ terhadap minat belajar, diperoleh $t_{\text {hitung }}>t_{\text {tabel }}$, yaitu 4,021 $>1,66$ dan nilai signifikansi $\alpha=0,05$ dengan standar error sebesar 0,09. Berdasarkan hasil tersebut, maka $\mathrm{H}_{0}$ ditolak, dan $\mathrm{H}_{1}$ diterima. Jadi terdapat pengaruh yang signifikan keaktifan siswa terhadap minat belajar. Sehingga semakin aktif siswa, semakin tinggi minat belajarnya. Berdasarkan hasil penelitian bahwa keaktifan siswa berpengaruh signifikan atau positif terhadap minat belajar dan minat belajar berpengaruh terhadap hasil belajar yang artinya semakin baik keaktifan siswa dalam pembelajaran maka semakin baik pula hasil belajar siswa yang akan diperoleh. Hal ini sejalan dengan Betha Nabila (2015), Artya Ningsih (2018) dengan judul "Pengaruh Keaktifan Siswa Terhadap Hasil Belajar".. Kemudian penelitian Fathiya Eka Putri (2019) dengan judul "Hubungan Antara Gaya Belajar dan Keaktifan Belajar Matematika Terhadap 
Hasil Belajar Siswa". Menunjukkan bahwa keaktifan siswa berpengaruh positif terhadap hasil belajar siswa.

\begin{tabular}{|ll|r|r|r|r|r|}
\hline Model & & Sum of Squares & \multicolumn{1}{|c|}{ df } & Mean Square & F & Sig. \\
\hline 1 & Regression & 722,182 & 2 & 361,091 & 19,888 &, $000^{\mathrm{b}}$ \\
& Residual & 1579,607 & 87 & 18,156 & & \\
& Total & 2301,789 & 89 & & & \\
\hline
\end{tabular}

a. Dependent Variable: Minat Belajar Siswa

b. Predictors: (Constant), Keaktifan Siswa, Komitmen Organisasi

Berdasarkan uji keberartian regresi linear ganda atau uji $\mathrm{F}$ diketahui bahwa nilai $\mathrm{F}_{\text {hitung }}$ $>\mathrm{F}_{\text {tabel}}$, yaitu 19,888 $>3,10$ dan nilai signifikansi $\alpha=0,05$. Hal ini berarti komitmen organisasi dan keaktifan siswa secara bersama-sama berpengaruh positif dan signifikan terhadap minat belajar siswa. Berdasarkan kesimpulan tersebut dapat dikatakan bahwa kecenderungan peningkatan komitmen organisasi dan keaktifan siswa akan diikuti peningkatan minat belajar siswa, sebaliknya kecenderungan penurunan komitmen organisasi dan keaktifan siswa akan diikuti penurunan minat belajar siswa.

\begin{tabular}{|c|c|c|c|c|}
\multicolumn{5}{|c|}{ Model Summary } \\
Model & $R$ & R Square & $\begin{array}{c}\text { Adjusted R } \\
\text { Square }\end{array}$ & $\begin{array}{c}\text { Std. Error of the } \\
\text { Estimate }\end{array}$ \\
\hline 1 &, $560^{\mathrm{a}}$ &, 314 &, 298 & 4,261 \\
\hline
\end{tabular}

a. Predictors: (Constant), Keaktifan Siswa, Komitmen Organisasi

Besarnya hubungan antara komitmen organisasi $\left(\mathrm{X}_{1}\right)$ dan minat belajar $(\mathrm{Y})$ adalah 0,43 sedangkan hubungan antara keaktifan siswa $\left(\mathrm{X}_{2}\right)$ dan minat belajar $(\mathrm{Y})$ adalah 0,44 . Dari data tersebut diperoleh nilai korelasi ganda (R) sebesar 0,56. Sehingga didapatkan koefisien determinasi $\left(\mathrm{R}^{2}\right)$ sebesar 0,314 artinya besarnya kontribusi komitmen organisasi $\left(\mathrm{X}_{1}\right)$ dan keaktifan siswa $\left(\mathrm{X}_{2}\right)$ terhadap minat belajar siswa $(\mathrm{Y})$ adalah sebesar 31,4 \%. Sisanya dipengaruhi oleh variabel lain yang tidak diteliti pada penelitian ini. Untuk penelitian selanjutnya, diharapakan peneliti bisa meneliti variabel lain yang mungkin bisa mempengarui penelitian.

\section{KESIMPULAN}

Dari hasil analisis data dan pembahasan yang telah diuraikan sebelumnya, maka dapat diambil kesimpulan sebagai berikut :

1) Terdapat pengaruh yang signifikan komitmen organisasi $\left(\mathrm{X}_{1}\right)$ terhadap minat belajar $(\mathrm{Y})$. Hal ini berdasarkan uji t, diperoleh $t_{\text {hitung }}>t_{\text {tabel, }}$, yaitu 3,883 $>1,66$ dan nilai signifikansi $\alpha$ $=0,05$ dengan standar error sebesar 0,04.

2) Terdapat pengaruh yang signifikan keaktifan siswa $\left(\mathrm{X}_{2}\right)$ terhadap minat belajar $(\mathrm{Y})$. Hal ini Berdasarkan uji $\mathrm{t}$, diperoleh $\mathrm{t}_{\text {hitung }}>\mathrm{t}_{\text {tabel, }}$ yaitu 4,021 $>1,66$ dan nilai signifikansi $\alpha=0,05$ dengan standar error sebesar 0,09.

3) Terdapat pengaruh yang signifikan secara simultan komitmen organisasi $\left(X_{1}\right)$ dan keaktifan siswa $\left(\mathrm{X}_{2}\right)$ terhadap minat belajar $(\mathrm{Y})$. Hal ini berdasarkan uji keberartian regresi linear ganda atau uji $\mathrm{F}$ diketahui bahwa nilai $F_{\text {hitung }}>F_{\text {tabel, }}$ yaitu 19,888 $>$ 3,10 dan nilai signifikansi $\alpha=0,05$.

4) Hasil uji koefisien determinasi $\left(\mathrm{R}^{2}\right)$ sebesar 0,314 artinya besarnya kontribusi komitmen organisasi $\left(\mathrm{X}_{1}\right)$ dan keaktifan siswa $\left(\mathrm{X}_{2}\right)$ terhadap minat belajar siswa $(\mathrm{Y})$ adalah sebesar $31,4 \%$. Sisanya dipengaruhi oleh variabel lain yang tidak diteliti pada penelitian ini.

\section{DAFTAR PUSTAKA}

Dimyati dan Mudjiono. (2010). Belajar dan Pembelajaran. Jakarta: Rineka Cipta.

Farikhah, U.I.; Syihabudhin dan Churiyah, M. (2012). Analisis Komitmen Organisasi dan 
Motivasi Berprestasi dalam Upaya Meningkatkan Kinerja Guru (Studi pada Guru SMA Laboratorium UM). Diakses dari fe.um.ac.id/wpcontent/uploads/2012/08/JurnalUlil.pdf.

Ferra Dwi Putri. (2017). Hubungan Minat Belajar Terhadap Prestasi Belajar Matematika Siswa Kelas IV SD Negeri se-Gugus Mawar Metro Pusat. Bandar Lampung: FKIP, Universitas Lampung.

Kusumastuti dan Nurtjahjanti. (2013). Komitmen Afektif Organisasi Ditinjau Dari Persepsi Terhadap Kepemimpinan Transaksional Pada Pekerja Pelaksana Di Perusahaan Umum(PERUM) X Semarang. Jurnal Studi Manajemen dan Organisasi UNDIP. Vol. 10, No. 1, Januari 2013.

Meyer, J.P. \& Herscovitch, L. (2001). Commitment in the Workplace : Toward General Model. Human Resource Management Review, 11, 299-326.

Molstad, C. E., \& Karseth, B. (2016). National Curricula in Norway and Finland: The Role of Learning Outcomes. European Educational Research Journal , 15 (3), 329-344.

Nurhasanah, Siti dan, A. Sobandi. (2016). Minat Belajar Sebagai Determinan Hasil Belajar Siswa (Learning Interest as Determinant Student Learning Outcomes). Jurnal Pendidikan Manajemen Perkantoran Vol. 1 No. 1, Hal. 128-135.

http://ejournal.upi.edu/index.php/jpmanper/article/view/00000

Raju, P. M. \& Srivastava, R.C. (1994). Factors Contributing to Commitment to The Teaching Proffesion. International Journal of Educational Management, Vol. 8 (5): 7-13.

Ratnawati, Anugrah dan Marimin. (2014). Pengaruh Kesiapan Belajar, Minat Belajar, Motivasi Belajar, Dan Sikap Siswa Terhadap Keaktifan Belajar Siswa Jurusan Administrasi Perkantoran Pada Mata Diklat Produktif Ap Di SMK Negeri 2 Semarang. EEAJ 3 (1) Economic Education Analysis Journal.

http://journal.unnes.ac.id/sju/index.php/eeaj

Rumidi, Sukandar. (2002). Metodologi Penelitian Petunjuk Praktis Untuk Peneliti Pemula. Yogyakarta: UGM Press.

Safitri, F. N., \& Kustini, S. (2014). Pengaruh Minat Belajar, Kondisi Sosial Ekonomi Orang Tua, dan Lingkungan Sekolah terhadap Prestasi Belajar Ekonomi Pada Siswa Kelas XI IPS SMA Negeri 4 Magelang Tahun Ajaran 2013/2014. Economic Education Analysis Journal 3 (2).

Sholeh, Khabib dkk. (2017). Persepsi Terhadap Minat Belajar Siswa Dan Komitmen Afektif Organisasi Guru SMK Di Kabupaten Kebumen. Unima Jurnal Edukasi Jurnal Penelitian \& Artikel Pendidikan Jurnal Vol. 9, No. 2, Desember 2017, Hal: 47-57 pISSN: 2085-1472, eISSN: 2579-4965

http://journal.ummgl.ac.id/nju/index.php/edukasi

Slameto. (2015). Belajar dan Faktor-fakto yang Mempengaruhi. Jakarta: Rineka Cipta.

Sopiah. (2008). Perilaku Organisasional. Malang: ANDI.

Sugiyono, (2008). Metode Penelitian Pendidikan. Bandung : CV Alfabeta 